\title{
THE APPRENTICE SYSTEM ON THE NEW YORK CENTRAL LINES
}

\author{
By C. W. Cross, \\ Superintendent of Apprentices, New York City.
}

The apprentice system recently introduced upon the New York Central lines, and now being extended as rapidly as possible throughout the system, is a development which could with great advantage be paralleled in manufacturing and commercial organizations. While it is too soon to judge accurately of the final results, those thus far apparent, and the very rational and practical methods which are being used, indicate that such efforts will very materially improve labor conditions and add greatly to the efficiency of the organizations making them.

Those who are familiar with the present labor situation, the lack of skilled mechanics, the difficulty in securing foremen and the gross neglect on most roads of a system for recruiting good men for these positions, must realize the need of improvement. The most forceful presentation of this subject which has ever been made, whether we consider the railroads alone or the manufacturing of commercial interests at large, was by Mr. G. M. Basford in a paper read before the Master Mechanics' Association in $1905 .{ }^{1}$ The necessity of installing such a system, and a general outline of a system, which would produce successful results, under present conditions, was clearly presented. These suggestions have been followed quite closely in working out the details on the New York Central lines.

The system adopted may be summed up under the following heads :

I. Close supervision and instruction of the apprentices in the shop by an apprentice instructor is provided.

2. A school is conducted by the company during working hours, at which mechanical drawing is taught in a practical way. The apprentice is paid for attendance.

"American Engineer," page 251, July, 1905.

(I63) 
3. A course of problems, carefully arranged to suit the needs of the apprentices, has been prepared. These they are expected to work out on their own time.

While the system differs radically in many respects from anything that has heretofore been done in this country, it follows more or less closely the general principles governing the educational system of the British Admiralty, which has been in operation more than sixty years and, according to Sir William $\mathrm{H}$. White, has produced the majority of the men who are now occupying the most prominent positions in the ship-building industries of Great Britain. He says of the system: "It has given to private ship-builders its leaders, who have risen from the ranks, while it has produced men holding many important and influential positions in all parts of the world."'

The only system that has been carried out on a large scale in this country, which at all approaches the methods used on the New York Central Lines, is that of the General Electric Company's apprentice school at Lynn, Mass. ${ }^{3}$ A special shop has been fitted up at Lynn known as the "Apprentice Training School," and for the first one and a half or two and a half years the boys work in this shop under the direction of competent instructors. The production of this department is of commercial value. The latter part of the course is spent on regular work in the shops. A school is conducted during working hours at the expense of the company, each apprentice receiving six hours' instruction a week.

Manufacturing industries are suffering greatly from the lack of suitable means for recruiting skilled labor, and unless immediate steps are taken to remedy the difficulty the commercial resources of the country will be seriously crippled. The same thing applies with equal force to the motive-power departments of our railroads.

It is true that here or there a railroad or a shop has given some attention to this subject, but generally speaking, it has been almost lost sight of. The old methods are not suitable for the new conditions, and an adequate system cannot be installed and carried on successfully as a side issue by an officer who has already all he can do. Fortunately the formation of large railroad systems, each made up of several railroads, makes it possible to place a work of this

"See article in "Techniques," January, 1904.

"Described in a paper on "A Plan to Provide for a Supply of Skilled Workmen," presented by Mr. Magnus W. Alexander at the December, 1906, meeting of the American Society of Mechanical Engineers. 
kind in the hands of a qualified man who can give his entire time to it and employ the necessary assistants.

It was with a clear understanding of this fact that the officials of the New York Central lines set about the formation of a school to train apprentices. The purpose of such movement, if it is to be successful, must be in line with the suggestions of Mr. G. M. Bashford, used in closing the discussion of his paper for the Master Mechanics' Association two years ago. "I beg you to bear in mind the pyramid-a pyramid of the rank and file, the rank and file of the workmen, upon whose shoulders you stand. As the base is great and upright and strong morally and intellectually, so is the structure. No structure is great and permanent that is not right at the bottom." If steps are taken to furnish a good supply of skilled workmen, well equipped for service under modern shop conditions, there will be no trouble in developing men from among them for the highest positions.

Although at the inauguration of the new plan there were twelve shops on the system, each of which had from twenty to seventyfour apprentices, apprentice schools of some kind had been carried on previously by the local managements at only four points-Elkhart, Ind.; Jackson, Mich.; Oswego, N. Y.; McKees Rocks, Pa.

\section{Development of the Apprentice Schools}

About thirty-five years ago an apprentice school was started at the Elkhart shops on the Lake Shore and Michigan Southern Railway. The sessions were held in the evening and the school was intended primarily for apprentices, although anyone in the employ of the company was eligible for membership. Instruction was continued with more or less success, and in rgor, under the direction of the writer, then the master mechanic, attendance was made compulsory for apprentices, and what was known as the apprentice association was organized. This association held meetings every two weeks, at which reports were made by committees who had visited other shops, or addresses were made by persons skilled in different classes of work. While membership in the association was not compulsory, the greater number of the apprentices belonged to it, and the meetings were well attended.

On July 28, r886, evening class work for the apprentices was started at the Jackson shops of the Michigan Central Railroad. 
For the first few months the classes were held from 7 to 9 p. m., but this did not prove satisfactory and the hours were changed to 5.15 to 7.15 p. m. Each class met one night a week from November Ist to April 3 oth. Attendance was made compulsory. In January, 1904, an apprentice school was organized at the Oswego shops of the New York Central under the direction of Mr. W. O. Thompson, division superintendent of motive power. This class met for two hours, one day of each week, directly after the whistle blew at the close of the day. Attendance was made compulsory for the apprentices, and they were paid for their time in the class, thus making it possible to enforce a somewhat more rigid discipline. About two years ago an evening school was organized at the McKees Rocks shops of the Pittsburgh and Lake Erie Railroad. The classes met twice a week and attendance of the apprentices was made compulsory. Mechanical drawing was taught at these four schools, the method being the same as that ordinarily followed, including practice in lettering, geometrical exercises, projections, copying of drawings and blue prints, making drawings of locomotive parts and making tracings.

The apprentice department of the New York Central lines was inaugurated on March I, 1906. On May 7, 1906, the first apprentice class, under this new plan, was started at the West Albany shop. It was realized, of course, that while there would be some advantages which would be almost immediately apparent, the most important results would not be noticeable for a number of years, and, therefore, before starting the organization steps were taken to insure its permanency for a period of sufficient length to enable the results to be clearly demonstrated.

\section{Organization of the School}

The department as at present organized is under the direction of the writer, superintendent of apprentices, who devotes his entire time to this work. Mr. H. Gardner, assistant superintendent of apprentices, has charge of the educational features. Mr. Gardner is a graduate of the Massachusetts Institute of Technology and was engaged for a number of years as an instructor. He has thus had exceptional opportunities for studying boys and young men of about the same type as the apprentices in railroad shops, and understands thoroughly how to arrange the work to hold their interest, and so 
they will understand how to apply what they have learned to practical purposes. This central organization, with offices at the Grand Central Station, New York City, deals with the general problems affecting the apprentice work, outlines the different courses, looks after the educational work, organizes new schools and keeps in close touch with all the needs of the institution.

The boys come into contact with actual shop conditions from the very first. At each of the larger shops are two instructors, a drawing instructor, who in most cases is the shop draftsman, and who has charge of the school work, and a shop instructor who gives his entire time to instructing the apprentices in their shop work and to seeing that they receive the proper shop experience. Both of these men report directly to the local officers of the road, who keep in close touch with the apprentice department. The apprentices are, therefore, instructed by men already in the service of the company, on the shop property during working hours and while under pay. The instruction is given in the shop on the regular tools and in the regular run of work. The schedules followed insure a thorough training in the trade and give the necessary variety of work.

The drawing and the problem courses are arranged to allow each apprentice to progress as rapidly as he desires, but so as to enable a single instructor to handle classes with as many as twentyfour students in a class. The work assigned is such as to fit the standards of the road. The students are taught to read in the language of the shop and to meet the special conditions locally existing.

\section{Method of Instruction}

The method of instruction differs radically from the ordinary methods of teaching in the following points:

(I) Text-books are not an essential part of the plan. (2) There is no sub-division into subjects. (3) All principles are clothed in problem form. (4) There is no arbitrary standard of the amount of ground to be covered. (5) No examinations are held. The progress and the marks of the apprentices are based on the close personal touch maintained between the instructors and the apprentices.

The apprentice work can be installed at the greater number of the shops by using talent already in the service of the company. The men in the shops, both foremen and workmen, have evinced 
considerable interest in the apprentice school, and there has been a demand for evening schools to give them the same advantages. In response to this desire, evening schools have been started at a number of places, including McKees Rocks (October, 1906), Elkhart (November, I906), Jackson (November, I906), West Albany (November, 1906), Brightwood (December, I906), Oswego (January, 1907), and Collinwood (February, 1907). These classes are open to all of the employees at all of the points except Elkhart and McKees Rocks. They meet for an hour and a half or two hours directly after the shop whistle blows in the evening. At Elkhart the classes meet from 7 to 9 and at McKees Rocks from $7 \cdot 30$ to $9.30 \mathrm{p} . \mathrm{m}$. The men are more regular in attendance and take a keener interest in the work when the meeting is held directly after the shop closes. In many cases the men live a considerable distance from the shop, and it would not be convenient for them to return after going home to their dinners.

The make-up of these classes is very interesting and will give some iclea of the extent to which this work has been carried. At several of the schools where there is a full quota of apprentices and a waiting list, the boys take places as helpers until there is an opening for them in the apprentice department. These boys usually enroll in the evening classes. Boys who have finished their apprenticeship also follow up their studies in connection with the evening classes.

The men who attend the evening classes take the same course as the apprentices, but if they lesire may skip the easier portions. As a rule they prefer to take all of the work, reviewing that part with which they are familiar. They furnish all of their own material and pay the instructor, the apprentice school drawing instructor, for his time. The cost of tuition amounts to about $\$ 1.25$ per month, which ordinarily includes nine lessons. The classes are held in the apprentice school room. the company furnishing this with light and heat, free. Only the drawing work is done in class, the problems being worked outside.

These evening classes give the more ambitious men an opportunity for becoming more proficient and to fit themselves for better positions. They are especially valuable for foremen and for assistant foremen who desire to "brush up" their knowledge of drawing and mathematics. As a result the shop men are beconing more familiar with the company standards and are being drawn into closer touch with the shop draftsmen. 


\section{Location of Schools}

The schoolroom should be located near the shop buildings from which the greater number of apprentices come, in order that as little time as possible will be lost in going to and from work, and so that the boys can conveniently drop in during the noon hour. The room should be well lighted and ventilated. Provision should be made if possible for sufficient blackboard space to send the entire class to the board at one time. Floor area, including the space occupied by the filing cases, racks or tables for models and the instructor's desk, should average at least twenty-five to thirty square feet to each member of the class.

At West Albany the schoolroom is on the ground floor of a building next to the machine shop and opposite the office building. A connecting room at one end contains the filing cases and large models. At Oswego, Depew, Jackson and Collinwood the schoolrooms are in the office building, the one at Depew being especially large and well lighted. At McKees Rocks a large room on the second floor of the storehouse, which is centrally located, is used. At Elkhart the school is held in a separate building which was formerly used by one of the other departments. It is well lighted, as it is comparatively narrow and has windows on both sides.

The building at Brightwood, on the Big Four, was built especially for the school. It is of frame construction, located conveniently, and the large amount of window space furnishes splendid light. The inside dimensions of the building are 25 by 50 by 13 feet high. The classes at this place meet twice a week for the first two hours in the morning. The boys are bright, fresh and clean at this time of day and able to do their best work. This is much more satisfactory than evening classes, as the boys are in a more receptive frame of mind than after a long day in the shops. The school is closed during the month of August. The boys ring in at the shop before coming to class, and at the close of the session proceed directly to the shop.

The total number of apprentices enrolled in the schools at the present time is about 50o. The total number of apprentices on the New York Central lines, not including the Boston and Albany, is 667. Extension to the other large shops of the company is taking place as rapidly as possible.

No attempt has been made to grade the classes according to the 
progress made by the students except at Oswego. At that place conditions at present are such that this can be done. Care is exercised that too many boys are not taken from any one clepartment in the shop at the same time, so as not to interfere too seriously with the shop work. The drawing course is arranged so that one instructor can look after as many as twenty-four boys at a time, although smaller classes may be handled to better advantage. The average number of students in a class is about seventeen.

\section{Character of Instruction}

The class work is largely mechanical drawing, although some time is devoted to blackboard exercises in connection with the problem course, and occasionally the instructor may find it advisable to talk to the class about the work in the drawing or problem courses. The students are also instructed from models as to shop practice and taught the principles of the steam engine and valve setting with the aid of a small stationary engine in the classroom.

The drawing course is very different from that ordinarily followed, and is based on strictly practical and common-sense lines. No time is wasted on geometrical exercises, but from the very first the student draws objects with which he is familiar and comes in contact in the shop. The first exercises are largely redrawing correctly sketches which are not in scale, the dimensions in all cases being taken from the model. New principles are introduced gradually, and progress is slow but very thorough. Like the drawing course, the problem course is eminently practical and based on shop practice and company standards. No matter how simple the problem, even in simple addition and subtraction, they refer to something with which the boy is familiar in connection with his work. The problems gradually grow more difficult, taking up the simpler principles of algebra, geometry, physics, elementary mechanics, etc., but these are introduced only when necessary to solve some practical problem and are not classified as such. The boys do the greater part of the problem work at home. It is not possible to use textbooks in connection with either of the above courses. The work must be arranged to suit the special conditions met with in a railroad shop, and to be effective the problems must be tied up closely to the shop work. For instance, the drawing and problem courses for the locomotive and car department are not alike. The drawing 
problems are arranged on blue print sheets and when a boy is ready a problem sheet and a model are handed to him, the sheet giving the directions as to what is to be done. In this way each boy in the class can work on a different problem, and yet the work of the instructor is very little more difficult than if all were on the same problem.

\section{The Drawing Instructor}

The success of any such system of instruction depends very largely upon selecting the proper men for instructors. The drawing instructor should preferably be the shop draftsman, thus being brought in close contact with shop problems and also with the men in the shop. He must be a man who will take a genuine interest in the boys, and who can see things from their point of view; a man that the boys will not fear to approach, either for information as to their class of problem work or for advice as to personal matters.

The instructor should be a man to whom the boys will look for advice and assistance in forming apprentice clubs or organizations, whether intended for ellucational or social purposes One instructor who is especially close to the boys is very often accosted on the street in the evening by boys who have questions to ask in connection with some problem. Some make a practice of calling on the boys at their homes when they have been absent from the shop due to illness or other causes. A quiet talk with a careless or indifferent boy often accomplishes remarkable results.

\section{The Shop Instructor}

The shop instructor is an important factor in the organization. At the larger shops he gives his entire time to looking after the apprentices. He instructs the boys at their trade and sees that they are changed from one class of work to another, in accordance with the apprentice schedules. In changing the apprentices about the instructors consult with the various foremen, studying the situation carefully, in order to have as little friction as possible in making the changes, and so as not to interfere too greatly with the efficiency of any one department. His suggestions must, of course, be approved by the shop superintendent before they go into effect.

With the school in operation the apprentices report to their foremen in the shops, as before, but the foremen are relieved of all 
responsibility of instructing them. Ordinarily very great returns are not to be expected from the introduction of an apprentice system until after a period of several years, but the work of the shop instructor has been found to affect almost immediately the shop output, and this is to be expected. The shop foremen are too busy to spend much time with the boys, and ordinarily the instruction in shop practice has been very much neglected, thus restricting the output and increasing the amount of spoiled work.

The shop instructor, like the drawing instructor, must have a great deal of patience with the boys and take a genuine interest in them. He must be a good mechanic, must have sufficient all-around knowledge to enable him to look after the boys in the various trades, and his position in the shop organization should be such that the boys will look up to him. Most of all, he should be a man who will appeal to the boys and know how to convey his ideas so that they will readily understand him. He should take a broad view of the shop problems, giving the boys some idea as to the general principles affecting their work, such, for instance, as movement of material through the shop, the cost of production and the elimination of lost motion in performing their work.

In addition to what financial compensation the drawing and shop instructors receive there are other important advantages to them. To handle their work successfully they must study up and become more familiar with the work in the various departments of the shops. They become familiar with shop practice at other points on the system by occasional visits. If they have marked executive ability it soon becomes apparent and this, with the broader view they have of the shop operation, fits them for more important positions in the organization. Nothing is quite so important in crystallizing one's ideas and broadening one's outlook as trying to instruct others.

\section{Equipment}

An effort has been made to provide sufficient blackboard space in each schoolroom, so that the entire class, if possible, may be sent to the board at one time. A standard drawing table is used at several shops, but at others the shape of the room, or equipment already at hand, made it advisable to deviate from this. The form favored is simple, but substantial and inexpensive. Drawing stools are furnished and are especially appreciated by the evening classes. 
Cases are provided for filing the drawing boards and tools. Each drawing board is numbered and is filed in a corresponding space in the case, the tools being placed in an orderly arrangement on top of the board.

Each boy is furnished with a pine drawing board, shellac finish, 18 by 24 by ${ }^{11} / 16$ inch thick. The boards have hardwood strips $1 / 4$ by I inch mortised in each end to keep them from warping. In addition, the boy is furnished with a T-square, celluloid triangle, a wooden curve, triangular box scale, thumb tacks, erasers, erasing shield, protractor, pencils, a file for sharpening the pencils, ink, pens and penholder and the necessary drawing and tracing paper. As these supplies are purchased in large quantities, the cost to the company is comparatively small. The boys are expected to provide their own drawing instruments, which, because of the large number of sets required, are comparatively inexpensive. A splendid set may be secured for $\$ 4.00$ and very satisfactory sets can be obtained as low as $\$ 2.50$.

Each school is provided with a small vertical engine and a light engine lathe, not necessarily new or up-to-date, which is used in connection with the drawing and problem course. Any number of practical problems may be based on the gearing; pulleys, etc., of the lathe, and the principles of steam distribution and valve setting are taught in connection with the engine. A combination stereopticon and reflection or opaque projection lantern has been purchased by the railroad company and is used in connection with lectures given. The testing laboratories, machinery and equipment, especially at the larger shops, afford exceptional opportunities for occasional practical demonstrations in connection with the class work.

\section{Appreciation of Opportunity}

The apprentices generally have displayed considerable interest in the work of the school and the efforts which are being made to improve their opportunities. This is clearly shown in a number of ways, especially by the earnestness with which the greater number of them are following up the drawing and problem courses. At several shops the writer called at the school during the noon hour, after the boys had eaten their lunch, and almost invariably, several of them would be found working on problems, looking up references. asking questions of the instructor or talking the work over among 
themselves. Some of the boys have completed their apprentice course since the school was inaugurated, but realizing the opportunity which was being placed before them, they have enrolled in the evening classes and are continuing their studies in that way.

While only two or three of the schools have been in operation for as long as two years, a number of practical advantages have become evident. With the greater opportunities that are being offered a better class of boys is being secured. Formerly it was difficult to keep up the full quota of apprentices at most of the shops. Now there is a waiting list for some of the trades at several shops and apprentices are being secured for trades formerly without them. The apprentices take a greater interest in their work in the shop, and because of the principles learned in connection with their educational work are better able to understand the instructions given to them and to carry them out intelligently. The anorentice schools give promise of becoming a permanent boon both to those instructed and to the company. The former advance more rapidly and their earning power is thus increased. The latter have less spoiled work to charge to the loss account and have greater surety of obtaining a steady and skilled labor supply. 